\title{
PERANAN PEMIMPIN INFORMAL TERHADAP PARTISIPASI ANGGOTA PESERTA PROGRAM PEMP DI PROVINSI SUMATERA BARAT
}

\author{
Oleh: \\ Ani Leilani \\ Dosen Jurusan Penyuluhan Perikanan Sekolah Tinggi Perikanan
}

\begin{abstract}
ABSTRAK
Penelitian tentang peranan pemimpin informal terhadap partisipasi anggota peserta program PEMP dilakukan pada bulan Oktober sampai dengan Desember 2008 di tiga Kabupaten Provinsi Sumatera Barat, dengan jumlah responden 33 orang. Penelitian ini bertujuan: (1) mengidentifikasi corak peranan yng ditampilkan pemimpin informal, (2) menemukan faktor-faktor yang mempengaruhi penampilan peranan pemimpin informal, (3) mendapatkan gambaran pengaruh penampilan pemimpin informal terhadap partisipasi masyarakat mengikuti program, (4) mendapatkan gambaran pengaruh dari partisipasi pada hasil pelaksanaan program. Hasil penelitian menunjukkan: 1) terdapat lima karakteristik partisipasi peserta program PEMP tergolong kategori sedang yaitu: pengambil keputusan, pelaksana kegiatan, pengawasan kegiatan, pengembangan kegiatan sosial, dan peningkatan ekonomi masyarakat, sedangkan sebagai penyusun rencana tergolong rendah, dan Partisipasi dalam menikmati hasil kegiatan tergolong tinggi ini menunjukkan bahwa program PEMP memberikan input/hasil yang baik kepada anggota kelompok baik dari segi bantuannya maupun pendampingannya, 2) peranan pemimpin informal dari 7 karakteristik yang dipilih sebagian besar (5 karakteristik) berada pada kategori sedang yaitu: penyadar masalah pemotivasi , pengarah kegiatan , pembina kerjasama , dan penghubung antar system . Sedangkan 2 karakteristik berada pada kategori tinggi diantaranya: pemberi informasi dan pemberi ganjaran , 3) sebagian besar karakteristik pribadi pemimpin informal yaitu: umur, pendidikan formal, lama memimpin, dan empaty berhubungan sangat nyata dengan partisipasi anggota dalam mengikuti program PEMP, hanya satu karakterstik yang menunjukkan tidak berhubungan nyata yaitu asal ketokohan,hal ini disebabkan oleh karena hampir seluruh responden adalah ketua kelompok pembudidaya yang merupakan tokoh informal yang berada pada garis depan pembangunan masyarakat dan merupakan panutan bagi anggota, dan 4) semua karakteristik pada peran pemimpin informal berhubungan sangat nyata dengan partisipasi anggota dalam mengikuti kegiatan PEMP. Hal tersebut menunjukkan bahwa pemimpin informal dapat menunjukkan perannya secara optimal sehingga tujuan dari program pemberdayaan masyarakat pesisir dapat terealisasi seperti meningkatkan kesejahteraan antara lain dengan cara penguatan modal pada Lembaga Keuangan Mikro (LKM), pengembangan kultur kewirausahaan (Pedum PEMP 2007).
\end{abstract}

Kata Kunci: Pemimpin Informal, Partisipasi, Program PEMP

\section{PENDAHULUAN}

\section{Latar Belakang}

Pendekatan pembangunan yang terima oleh ahli pembangunan adalah pendekatan dari bawah ke atas (bottom up) yang berarti bahwa pembangunan diperlukan partisipasi atau keikutseraan masyarakat. Partisipasi tidak hanya pada tahap perencanaan pembangunan, akan tetapi juga partisipasi dalam melaksanakan, bahkan sampai pada menilai dan 
mengevaluasi hasilnya. Partisipasi masyarakat desa dalam program pembangunan cenderung dilakukan secara berkelompok, yang mana terdapat seorang ketua kelompok yang berfungsi sebagai pemimpin. Dalam sebuah komunitas pedesaan selain pemimpin kelompok atau kontak tani, juga terdapat beberapa tokoh yang dianggap sebagai pemimpin, seperti: pemuka agama, tokoh adat, dan tokoh masyarakat lainnya, yang kesemuanya itu biasa disebut pemimpin informal.

Keikutsertaan pemimpin informal dalam pembangunan desa sangat penting, sebab pembangunan desa akan mengalami hambatanhambatan jika pemimpin informal tidak dilibatkan. Di sisi lain keikutsertaan pemimpin informal dalam pembangunan akan berjalan lancar, karena mereka merasa memiliki tanggung jawab moral atas kemajuan desa.

Di beberapa daerah di Indonesia pemimpin informal tampak memegang teguh pesan atau amanah leluhur untuk kemajuan desanya. Pemimpin informal yang demikian menampilkan kepemimpinannya berdasarkan kharisma, kearifan serta sifat-sifat personal lain yang mendorong keikutsertaan masyarakat dalam pembangunan.

Pengakuan pentingnya kedudukan pemimpin informal perlu didukung oleh adanya kesempatan kepada mereka untuk menampilkan (mengekspresikan) sejumlah peranan sesuai dengan harapan pengikutnya. Peranan yang diharapkan pengikut harus berorientasi dan selaras dalam upaya membawa dan mendorong pengikut melakukan aktivitas pembangunan. Karena itu peranan pemimpin demikian itu dapat disebut sebagai peranan pembangunan. Peranan seperti ini diarahkan terutama untuk menggerakkan warga agar berpartisipasi dalam melakukan berbagai pembaruan yang berwujud program pembangunan.

Mengacu pada uraian di atas, pokok masalah penelitian adalah: "Bagaimana penampilan peranan pemimpin informal masyarakat di pedesaaan, yang mampu menggerakkan masyarakat agar berpartisipasi dalam pembangunan desa?"

\section{Masalah Penelitian}

Berdasarkan pokok masalah yang diuraikan di atas, maka masalah dirumuskan dalam pertanyaanpertanyaan penelitian sebagai berikut: (1) peranan apa yang ditampilkan pemimpin informal, (2) bagaimana menampilkannya, (3) apa hasil penampilan tersebut, dan (4) bagaimana respon pengikut dalam wujud partisipasi mereka dalam mengikuti program pembangunan.

\section{Tujuan Penelitian}

Sejalan dengan permasalahan tersebut, maka penelitian ini bertujuan antara lain: (1) mengidentifikasi corak peranan yng ditampilkan pemimpin informal, (2) menemukan faktor-faktor yang mempengaruhi penampilan peranan pemimpin informal, (3) mendapatkan gambaran pengaruh penampilan pemimpin informal terhadap partisipasi masyarakat mengikuti program, (4) mendapatkan gambaran pengaruh dari partisipasi pada hasil pelaksanaan program.

\section{Manfaat Hasil Penelitian}

Penelitian ini dilakukan dengan harapan dapat memberikan manfaat antara lain: (1) memberikan masukan dalam menyusun strategi penyuluhan yang efektif terhadap pemimpin informal di pedesaan, (2) bahan masukan bagi penentu kebijakan 
pembangunan desa, terutama pembangunan yang berorientasi pada upaya peningkatan gerakan membangun diri secara swadaya dalam masyarakat.

\section{KERANGKA PEMIKIRAN DAN HIPOTESIS}

\section{Kerangka Pemikiran}

Pemimpin informal menampilkan berbagai peranan dalam menyadarkan pengikut tentang perlunya mengadakan pembaruan, dengan demikian upaya untuk mengetahui dan mengukur derajat penampilan peranan pemimpin informal, sama dengan mengukur partisipasi warga dalam melakukan atau mengikuti program pembangunan. Pengukuran ini akan lebih mudah bila diketahui motor penggerak yang mendorong warga untuk berpartisipasi.

Sumber daya pendorong dapat dikategorikan ke dalam dua bagian, yaitu: (1) dari dalam diri warga, dan (2) dari luar, khususnya pemimpin dan kelompok lain yang telah mencapai kemajuan secara umum. Pemimpin informal dapat menjadi motor penggerak apabila mempunyai kemampuan untuk itu. Kemampuan itu dapat diperoleh melalui dua cara: (1) mendekatkan diri kepada penyuluh dalam arti penyuluh berupaya meningkatkan dan membangun kepemimpinan pedesaan, (2)pemberian dorongan dan bimbingan dari pejabat kepada pemimpin, dan (3) mempergunakan informasi yang bersumber dari media massa.

Berdasarkan uraian-uraian yang telah dikemukanan, maka keberhasilan program PEMP dalam pengembangan kegiatan sosial untuk peningkatan perekonomian masyarakat bergantung dari adanya partisipasi anggota masyarakat, terutama dalam pengambilan keputusan, penyusunan rencana kegiatan yang akan dilakukan, pelaksanaan kegiatan, pengawasan, dan menikmati hasil program pembangunan.

Keberhasilan pemimpin
informal menumbuhkan partisipasi
warga masyarakat sangat ditentukan
oleh penampilan peranannya, meliputi:
(1) menyadarkan adanya masalah
kepada anggota, (2) memberikan
informasi, (3) mendorong dan
memotivasi untuk berubah, (4)
mengarahkan kegiatan untuk mencapai
tujuan bersama, (5) memberikan
ganjaran atau sanksi, dan (6) bertindak
sebagai penghubung antar sistem. Di
samping itu ciri pribadi pemimpin
informal seperti; umur, tingkat
pendidikan formal, lama atau
pengalaman memimpin, asal
ketokohan dalam masyarakat, dan rasa
empati.

\section{Hipotesis}

Berdasarkan kerangka pikir di atas, dapat dirumuskan hipotesis penelitian, yakni: (1) karakteristik pribadi pemimpin informal berpengaruh nyata terhadap peningkatan partisipasi anggota mengikuti program PEMP, (2) peranan pemimpin informal berpengaruh nyata terhadap peningkatan partisipasi anggota mengikuti program PEMP, (3) terdapat hubungan nyata karakteristik pribadi dan peranan pemimpin informal dalam mendorong partisipasi anggota mengikuti program PEMP. Secara skematis, hipotesis penelitian tersaji pada Gambar 1. 


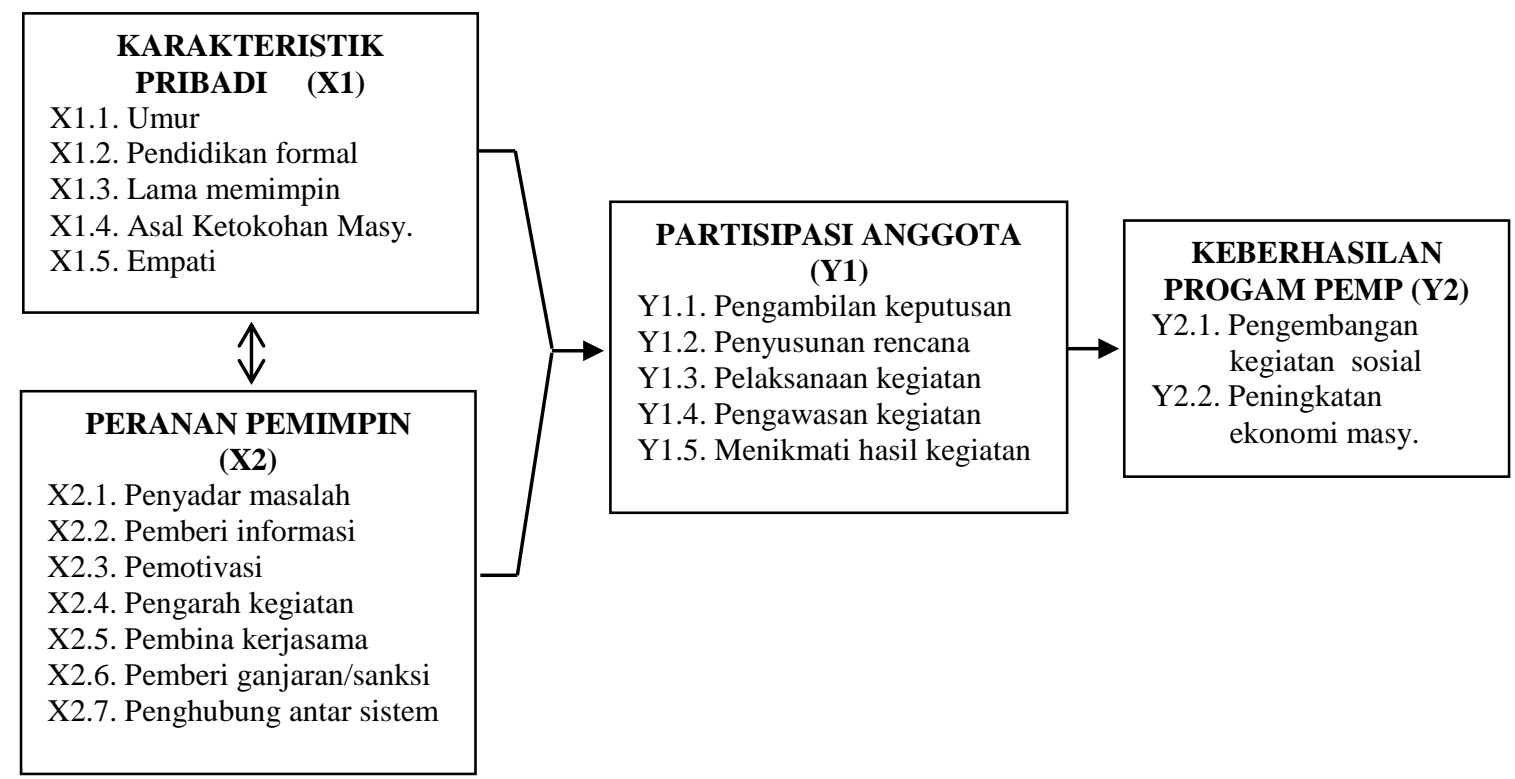

Gambar 1. Kerangka hipotetik hubungan karakteristik pribadi dan peranan pemimpin informal

\section{METODE PENELITIAN}

\section{Rancangan Penelitian}

Penelitian ini dirancang sebagai penelitian eksplanotoris, yaitu penelitian survei yang bertujuan menjelaskan pengaruh atau mengkaji hubungan antara peubah-peubah penelitian, melalui pengujian hipotesis yang telah dirumuskan sebelumnya.

\section{Lokasi dan WaktuPenelitian}

Lokasi penelitian adalah di Kabupaten Padang Pariaman Provinsi Sumatera Barat, yang berlangsung dari Bulan Oktober 2008 sampai dengan Desember 2008.

\section{Populasi dan Sampel}

Populasi penelitian adalah semua pemimpin informal di pedesaan di Kabupaten terpilih. Dari seluruh wilayah kabupaten, dipilih Kecamatan yang sedang atau telah mengikuti Program PEMP. Menurut data administrasi terdapat tiga kecamatan yang melaksanakan kegiatan PEMP yaitu kecamatan Bungus, Sungai Limau, dan Lubuk Basung dengan jumlah populasi 50 orang dengan rincian masing- masing populasi 12 orang, 20 orang, dan 18 orang.

\section{Dengan mengikuti rumus} Slovin (Umar, 2004) sebagai berikut:

$$
\begin{aligned}
& \mathrm{N}=\frac{\mathrm{N}}{------} \\
& \begin{array}{ll}
\text { Keterangan: } & \mathrm{n}=\text { besarnya sampel } \\
& \mathrm{N}=\text { besarnya populasi } \\
& \mathrm{e}=\text { batas error }(0,1)
\end{array}
\end{aligned}
$$

Berdasarkan rumus di atas, jumlah sampel adalah sebanyak 35,95 atau dibulatkan menjadi 36 orang, sehingga rincian sampel di masingmasing kecamatan Bungus (10 orang), Sungai Limau (20 orang), dan Lubuk Basung (11 orang), sehingga jumah sampel 33 orang.

\section{Pengumpulan Data}

Pengumpulan data dilakukan
dengan menggunakan seperangkat
instrumen berupa kuesioner yang berisi
pertanyaan atau pernyataan yang bersifat


tertutup (memilih alternatif jawaban yang tersedia, kecuali untuk peubah karakteristik pribadi).

Kuesioner dibuat berdasarkan indikator dan parameter seperti pada Tabel 3. Kuesioner disusun untuk responden pemimpin informal. Pengumpulan data dilakukan oleh peneliti dan dibantu oleh beberapa orang petugas/pendamping kegiatn PEMP setempat, dengan terlebih dahulu mendapat arahan seperlunya dari peneliti.

\section{Analisis Data}

Data yang terhimpun diolah secara deskriptif untuk mengetahui distribusi pemimpin informal berdasarkan peubah karakteristik pribadi. Selanjutnya dilakukan analisis untuk menguji hubungan antar peubah yang diamati, dengan menggunakan teknik analisis regresi dan korelasional Parson. Analisis data menggunakan piranti program (software) SPSS versi 15.

\section{HASIL DAN PEMBAHASAN}

\section{Karakteristik Pemimpin Informal}

Karakteristk pemimpin informal yang diamati dalam penelitian ini adalah: 1) umur, 2) pendidikan formal, 3) lama memimpin, 4) Asal ketokohan, dan 5) Empati.

Hasil penelitian tentang distribusi karakteristik pemimpin informal dapat dilihat pada Tabel 1 . berikut:

Tabel 1. Karakteristik Pemimpin Informal yang Diamati.

\begin{tabular}{|l|c|c|c|}
\hline \multirow{2}{*}{$\begin{array}{c}\text { Karakteristik Pemimpin } \\
\text { Informal }\end{array}$} & Kategori & \multicolumn{2}{|c|}{ Jumlah } \\
\cline { 2 - 4 } & & n & \% \\
\hline Umur & Muda & 8 & 24,2 \\
& Sedang & 21 & 63,7 \\
& Tua & 4 & 12,1 \\
\hline Pendidikan Formal & Rendah & 6 & 18,2 \\
& Sedang & 16 & 48,5 \\
& Tinggi & 11 & 33,3 \\
\hline Lama Memimpin & Sebentar & 3 & 9,1 \\
& Cukup & 15 & 45,5 \\
& Lama & 15 & 45,5 \\
\hline Asal Ketokohan & Penyuluh Tenaga & 1 & 3,0 \\
& Kontrak & 32 & 97,0 \\
\hline Empaty & Tokoh Masyarakat & 32 & 57,6 \\
& Rendah & 19 & 33,3 \\
& Sedang & 11 & 9,1 \\
\hline
\end{tabular}

Sumber: Data Primer diolahTahun 2009

Tabel 1 memperlihatkan bahwa umur pemimpin informal $63 \%$ menunjukkan umur sedang yaitu rata-rata berumur produktif, sebagian besar responden menamatkan pendidikan SMU yaitu $48 \%$ dengan kategori sedang. Lama memimpin pada pemimpin informal rata rata pada kategori cukup dan lama, masing-masing $45,5 \%$ ini menunjukkan bahwa pemimpin informal sangat berperan dalam kelanggengan anggotanya.
Sedangkan asal ketokohan pemimpin informal hampir seluruhnya berasal dari tokoh masyarakat yaitu seseorang yang memiliki sifat dan pembawaan yang membuat orang menyukainya. Pemimpin informal dari responden terpilih kurang berempati terhadap anggotanya yaitu $57 \%$ pada kategori rendah, rendahnya empaty disebabkan karena ada anggapan dari pemimpin 
informal bahwa anggotanya mempunyai hak yang sama dengan anggota lain dalam berpartisipasi terhadap program PEMP.

\section{Peranan Pemimpin Informal}

Peranan pemimpin informal sebagai: 1) penyadar masalah, 2) pemberi informasi, 3) pemotivasi, 4) pengarah kegiatan, 5) Pembina kerjasama, 6) pemberi ganjaran, dan 7) penghubung antar sistem dapat dilihat pada distribusi responden seperti pada Tabel 2 berikut:

Tabel 2. Peranan Pemimpin Informal

\begin{tabular}{|l|c|c|c|}
\hline \multicolumn{1}{|c|}{ Karakteristik Peranan } & Kategori & \multicolumn{2}{|c|}{ Jumlah } \\
\cline { 2 - 4 } Pemimpin Informal & & N & \% \\
& & 6 & 18,2 \\
& Rendah & 14 & 42,4 \\
& Sedang & 13 & 39,4 \\
\hline Penyadar Masalah & Tinggi & 10 & 30,3 \\
& Rendah & 11 & 33,3 \\
& Sedang & 12 & 36,4 \\
\hline Pemotivasi & Tinggi & 7 & 21,2 \\
& Rendah & 15 & 45,5 \\
& Sedang & 11 & 33,3 \\
\hline Pengarah Kegiatan & Tinggi & 7 & 21,2 \\
& Rendah & 15 & 45,5 \\
& Sedang & 11 & 33,3 \\
\hline Pembina Kerjasama & Tinggi & 9 & 27,3 \\
& Rendah & 14 & 42,4 \\
& Sedang & 10 & 30,3 \\
\hline Pemberi Ganjaran & Tinggi & 10 & 30,3 \\
& Rendah & 11 & 33,3 \\
& Sedang & 12 & 36,4 \\
\hline Penghubung Antar Sistem & Tinggi & 6 & 18,2 \\
& Rendah & 14 & 42,2 \\
& Sedang & 13 & 39,4 \\
\hline
\end{tabular}

Sumber: Data Primer diolah Tahun 2009

Tabel 2 memberikan gambaran bahwa peranan pemimpin informal dari 7 karakteristik yang dipilih sebagian besar (5 karakteristik) berada pada kategori sedang yaitu: penyadar masalah ( 42,4\%), pemotivasi $(45,5 \%)$, pengarah kegiatan $(45,5 \%)$, pembina kerjasama $(42,4 \%)$, dan penghubung antar system (42,4\%). Sedangkan 2 karakteristik berada pada kategori tinggi diantaranya: pemberi informasi $(36,6 \%)$ dan pemberi ganjaran $(36,4 \%)$. Data diatas menunjukkan bahwa peranan peminpin informal bukan hanya sekedar pemimpin tetapi benar-benar telah memperoleh pengakuan dari seluruh anggotanya sebagai orang yang memiliki pengetahuan dan keterampilan untuk dapat mengkoordinasikan anggotanya sesuai dengan tujuan dan mengekspresikan kepemimpinannya dengan baik. Selain itu disamping pengalaman, kewibawaannya serta kharismatiknya peranan yang ditampilkan oleh pemimpin informal di Kabupaten padang pariaman termasuk kategori yang baik sesuai pernyataan Mardikanto (1996). 


\section{Partisipasi Peserta ProgrPEMP}

Partisipasi

peserta

terhadapprogram PEMP dantaranya sebaga: 1) Pengambil keputusan, 2) Penyusun rencana, 3) Pelaksana kegiatan, 4) Pengawasan kegiatan, 5) Menikmati hasil kegiatan, 6) Pengembangan kegiatan sosial, dan 7) Peningkatan ekonomi masyarakat dapat dilihat pada Tabel 3.

Keberhasilan suatu program ditentukan oleh tingkat partisipasi masyarakat atau anggota suatu kelompok, baik dalam menyumbangkan masukan (in put) maupun dalam menikmati hasilnya, sesuai pernyatan Slamet (1994), bahwa partisipasi adalah adanya proses kebersamaan dalam sesuatu aktivitas untuk mencapai tujuan tertentu. Ikut memberikan kontribusi terhadap suatu tujuan yang akan dicapai bersama, hal tersebut menyangkut kemauan bertanggung jawab dan kemauan menanggung akibat dari tindakan-tindakan yang dilakukan seperti tumbuh oleh karena adanya kerjasama yang baik yang dilandasi oleh keterbukaan, kebersamaan dan saling pengertian diantara individuindividu yang terlibat itu.

Partisipasi dapat terwujud apabila ada: 1) kemauan, 2) kemampuan ,dan 3) kesempatan dari anggota masyarakat. Tabel 3 menunjukkan bahwa partisipasi peserta program PEMP pada pengambil keputusan tergolong sedang yaitu $36,4 \%$, sebagai penyusun rencana tergolong rendah yaitu hanya $36,4 \%$, sedangkan sebagai pelaksana kegiatan dan pengawasan kegiatan masuk dalam kategori sedang masing-masing $42,4 \%$ dan $60,6 \%$. Partisipasi dalam menikmati hasil kegiatan tergolong tinggi yaitu 48,5\% ini menunjukkan bahwa program PEMP memberikan input/hasil yang baik kepada anggota kelompok baik dari segi bantuannya maupun pendampingannya. Dapak dari partisipasi peserta proam PEMP dapat mengembangkan kegiatan sosial di masayarakat, menurut hasil penelitian masih tergolong sedang yaitu sebesar $60,6 \%$ dan dampat dalam peningkatan ekonomi masyarakatpun tergolong sedang yaitu $63,6 \%$.

Tabel 3. Partisipasi Peserta Program PEMP

\begin{tabular}{|c|c|c|c|}
\hline Karakteristik & Kategori & & \\
\hline & & $\mathbf{n}$ & $\%$ \\
\hline Pengambil Keputusan & Rendah & 11 & 33,3 \\
\hline & Sedang & 12 & 36,4 \\
\hline & Tinggi & 10 & 30,3 \\
\hline Penyusun Rencana & Rendah & 12 & 36,4 \\
\hline & Sedang & 8 & 54,5 \\
\hline & Tinggi & 3 & 9,1 \\
\hline Pelaksanaan Kegiatan & Rendah & 13 & 39,4 \\
\hline & Sedang & 14 & 42,4 \\
\hline & Tinggi & 6 & 18,2 \\
\hline Pengawasan Kegiatan & Rendah & 6 & 18,2 \\
\hline & Sedang & 20 & 60,6 \\
\hline & Tinggi & 7 & 21,2 \\
\hline Menikmati Hasil Kegiatan & Rendah & 3 & 9,1 \\
\hline & Sedang & 14 & 42,4 \\
\hline & Tinggi & 16 & 48,5 \\
\hline Pengembangan Kegiatan Sosial & Rendah & 3 & 9,1 \\
\hline & Sedang & 20 & 60,6 \\
\hline & Tinggi & 10 & 30,3 \\
\hline Peningkatan Ekonomi Masyarakat & Rendah & 4 & 12,1 \\
\hline & Sedang & 21 & 63,6 \\
\hline & Tinggi & 8 & 24,2 \\
\hline
\end{tabular}

Sumber: Data Primer diolahTahun 2009 


\section{Hubungan karakteristik pribadi dan peranan pemimpin informal terhadap partisipasi anggota dalam mengikuti program PEMP.}

Sampson (Rakhmat, 2001) menyatakan faktor internal/pribadi individu merupakan ciri-ciri yang dimiliki oleh seseorang yang berhubungan dengan semua aspek kehidupan dan lingkungannya. Karakteristik tersebut terbentuk oleh faktor-faktor biologis dan sosiopsikologis. Karakteristik pribadi merupakan salah satu faktor yang penting untuk diketahui seperti perilaku yang ditunjukkan.

Hasil penelitian menunjukkan bahwa sebagian besar karakteristik pribadi pemimpin informal yaitu: umur, pendidikan formal, lama memimpin, dan empati berhubungan sangat nyata dengan partisipasi anggota dalam mengikuti program PEMP, hanya satu karakterstik yang menunjukkan tidak berhubungan nyata yaitu asal ketokohan,hal ini disebabkan oleh karena hampir seluruh responden adalah ketua kelompok pembudidaya yang merupakan tokoh informal yang berada pada garis depan pembangunan masyarakat dan merupakan panutan bagi anggota dan tidak berpengaruh terhadap aktivitas kegiatan karena dianggap mempunyai peran yang sama untuk mendapatkan program PEMP, umur yang produktif, pendidikan yang memadai, serta lamanya memimpin dalam kelompok akan menentukan tingkat partisipasi yang optimal bagi seseorang untuk dapat mengikuti seluruh kegiatan yang diprogramkan oleh PEMP. Sedangkan empati seseorang sangat mempengaruhi perilaku seseorang tersebut untuk bertindak dan melakukan sesuatu sesuai dengan kharisma yang ada pada seseorang tersebut, seperti yang tergambar pada Tabel 4.

Tabel 4. Hubungan antara karakteristik internal dengan partisipasi anggota dalam mengikuti program PEMP

\begin{tabular}{|c|c|c|c|c|c|c|c|}
\hline \multirow{2}{*}{$\begin{array}{c}\text { Karakteristik } \\
\text { Internal }\end{array}$} & \multicolumn{7}{|c|}{ Partisipasi Anggota dalam Mengikuti Program PEMP } \\
\hline & $\begin{array}{l}\text { Pengambil } \\
\text { Keputusan }\end{array}$ & $\begin{array}{c}\text { Penyusun } \\
\text { Rencana }\end{array}$ & $\begin{array}{c}\text { Pelaksana } \\
\text { Kegiatan }\end{array}$ & $\begin{array}{c}\text { Pengawasan } \\
\text { Kegiatan }\end{array}$ & $\begin{array}{c}\text { Menikmati } \\
\text { Hasil } \\
\text { Kegiatan }\end{array}$ & $\begin{array}{l}\text { Pengembangan } \\
\text { Kegiatan Sosial }\end{array}$ & $\begin{array}{l}\text { Peningkatan } \\
\text { Ekonomi } \\
\text { Masyarakat }\end{array}$ \\
\hline Umur & $0,873 * *$ & $0,863 * *$ & $0,879 * *$ & $0,808 * *$ & $0,915 * *$ & $0,761 * *$ & $0,755 * *$ \\
\hline $\begin{array}{l}\text { Pendidikan } \\
\text { Formal }\end{array}$ & $0,882 * *$ & $0,732 * *$ & $0,782 * *$ & $0,872 * *$ & $0,797 * *$ & $0,889 * *$ & $0,833 * *$ \\
\hline $\begin{array}{c}\text { Lama } \\
\text { Memimpin }\end{array}$ & $0,883 * *$ & $0,872 * *$ & $0,870 * *$ & $0,729 * *$ & $0,944 * *$ & $0,769 * *$ & $0,718 * *$ \\
\hline $\begin{array}{c}\text { Asal } \\
\text { Ketokohan }\end{array}$ & 0,217 & 0,219 & 0,201 & 0,287 & 0,309 & 0,322 & 0,316 \\
\hline Empaty & $0,800 * *$ & $0,703 * *$ & $0,767 * *$ & $0,660 * *$ & $0,843 * *$ & $0,767 * *$ & $0,678 * *$ \\
\hline
\end{tabular}

Sumber: Data Primer diolah Tahun 2009

Keterangan: $* *$ Berhubungan sangat nyata pada $\alpha=0,01$ 
Tabel 5. Hubunan antara peranan pemimpin informal dengan partisipasi anggota dalam mengikuti program PEMP

\begin{tabular}{|c|c|c|c|c|c|c|c|}
\hline \multirow{2}{*}{$\begin{array}{l}\text { Peranan } \\
\text { Pemimpin } \\
\text { Informal }\end{array}$} & \multicolumn{7}{|c|}{ Partisipasi Anggota dalam Mengikuti Program PEMP } \\
\hline & $\begin{array}{l}\text { Pengambil } \\
\text { Keputusan }\end{array}$ & $\begin{array}{c}\text { Penyusun } \\
\text { Rencana }\end{array}$ & $\begin{array}{c}\text { Pelaksana } \\
\text { Kegiatan }\end{array}$ & $\begin{array}{c}\text { Pengawasan } \\
\text { Kegiatan }\end{array}$ & $\begin{array}{c}\text { Menikmati } \\
\text { Hasil } \\
\text { Kegiatan }\end{array}$ & $\begin{array}{l}\text { Pengembangan } \\
\text { Kegiatan Sosial }\end{array}$ & $\begin{array}{c}\text { Peningkatan } \\
\text { Ekonomi } \\
\text { Masyarakat }\end{array}$ \\
\hline $\begin{array}{l}\text { Penyadar } \\
\text { Masalah }\end{array}$ & $0,855^{* *}$ & $0,749 * *$ & $0,789 * *$ & $0,826 * *$ & $0,857 * *$ & $0,820 * *$ & $0,777 * *$ \\
\hline $\begin{array}{l}\text { Pemberi } \\
\text { Informasi }\end{array}$ & $0.937 * *$ & $0,833 * *$ & $0,852^{* *}$ & $0,767 * *$ & $0,837 * *$ & $0,808 * *$ & $0,746^{* *}$ \\
\hline Pemotivasi & $0,898 * *$ & $0,755 * *$ & $0,798 * *$ & $0,847 * *$ & $0,800 * *$ & $0,673^{* *}$ & $0,814 * *$ \\
\hline $\begin{array}{l}\text { Pengarah } \\
\text { Kegiatan }\end{array}$ & $0,898 * *$ & $0,755^{* *}$ & $0,798 * *$ & $0,847 * *$ & $0,800 * *$ & $0,873 * *$ & $0,814 * *$ \\
\hline $\begin{array}{l}\text { Pembina } \\
\text { Kerjasama }\end{array}$ & $0,954 * *$ & $0,805 * *$ & $0,839 * *$ & $0,827 * *$ & $0,788 * *$ & $0,882 * *$ & $0,810 * *$ \\
\hline $\begin{array}{l}\text { Pemberi } \\
\text { ganjaran }\end{array}$ & $0,937 * *$ & $0,833 * *$ & $0,852 * *$ & $0,767 * *$ & $0,837 * *$ & $0,808 * *$ & $0,746^{* *}$ \\
\hline $\begin{array}{l}\text { Penghubung } \\
\text { Antar } \\
\text { Sistem }\end{array}$ & $0,855^{* *}$ & $0,749 * *$ & $0,789 * *$ & $0,826 * *$ & $0,857 * *$ & $0,820 * *$ & $0,777 * *$ \\
\hline
\end{tabular}

Sumber: Data Primer diolah Tahun 2009

Keterangan: ** Berhubungan sangat nyata pada $\alpha=0,01$

Tabel 5 diatas menunjukkan semua karakteristik pada peran pemimpin informal yaitu sebagai: penyadar masalah, pemberi informasi, pemotivasi, pengarah kegiatan, pembina kerjasama, pemberi ganjaran, dan penghubung antara sistem berhubungan sangat nyata dengan partisipasi anggota dalam mengikuti kegiatan PEMP. Hal tersebut menunjukkan bahwa pemimpin informal dapat menunjukkan perannya secara optimal sehingga tujuan dari program pemberdayaan masyarakat pesisir dapat terealisasi seperti meningkatkan kesejahteraan antara lain dengan cara penguatan modal pada Lembaga Keuangan Mikro (LKM), pengembangan kultur kewirausahaan (Pedum PEMP 2007).

Penggalangan partisipasi masyarakat sangat penting dalam menumbuhkembangkan suatu usaha sehingga ekonomi masyarakat dapat meningkat. Partisipasi masyarakat pengikut program PEMP dalam mengambil keputusan, menyusun rencana, mengawasi kegiatan,menikmati hasil kegiatan, yang akhirnya dapat mengembangkan kegiatan sosial dan meningkatkan ekonomi masyarakat

Menurut Slamet (2003), bahwa sifat-sifat yang perlu dimilki oleh seorang pemimpin informal selain dapat memerankan fungsinya dengan baik, maka harus mempunyai sifat: empati, menjadi anggota kelompok,bijaksana, lincah, beremosi stabil, sedangkan sifat tambahan yang dapat mendukung kelompok informal tetap solid adalah ada rasa ingin memimpin, kompeten, cerdas, konsisten, percaya diri, dan mampu berbagi kepemimpinan.

\section{KESIMPULAN DAN SARAN}

\section{Kesimpulan}

Berdasarkan pembahasan yang telah dilakukan, dapat disimpulkan sebagai berikut:

1. Sebagian besar dari pemimpin informal seperti penyadar masalah $(42,4 \%)$, pemotivasi $(45,5 \%)$, pengarah kegiatan (45,5\%), pembina kerjasama $(42,4 \%)$, dan penghubung antar sistem $(42,4 \%)$ termasuk pada kategori sedang, kecuali peran pemimpin informal sebagai pemberi informasi $(36,6 \%)$ dan pemberi ganjaran $(36,4 \%)$ termasuk pada kategori tinggi.

2. Mayoritas partisipasi peserta program PEMP termasuk pada kategori sedang, yaitu partisipasi dalam pengambil keputusan $(36,4 \%)$, pelaksana kegiatan $(42,4 \%)$, pengawasan kegiatan $(60,6 \%)$, pengembangan kegiatan sosial $(60,6 \%)$, dan peningkatan ekonomi masyarakat $(63,6 \%)$. 
Sedangkan partisipasi dalam menyusun rencana rendah $(36,4 \%)$, dan partisipasi dalam menikmati hasil kegiatan tinggi $(48,5 \%)$.

3. Terdapat hubungan yang sangat nyata antara peranan pemimpin informal dengan partisipasi anggota dalam mengikuti program PEMP.

\section{Saran}

Berdasarkan hasil penelitian, dapat disarankan:

1. Perlu dilakukan penelitian serupa dengan responden yang lebih banyak terhadap program-program yang dapat meningkatkan kapasitas sasaran.

2. Perlu dirumuskan batasan-batasan partisipasi sasaran maupun pemimpin informal dalam melakukan suatu kegiatan penyuluhan baik yang bersifat rutin maupun program-program.

3. Perlu adanya peningkatan kualitas pemimpin informal melalui pelatihan maupun pendampingan secara rutin sehingga dapat memerankan fungsinya dalam membina anggota secara maksimal.

\section{DAFTAR PUSTAKA}

Anonim, 2006. Kepemimpinan Masyarakat Adat. Modul Pember- dayaan Masyarakat Adathttp://www.ireyogya.org/ad at/htm. Di akses tanggal, 20 November 2007.

Asngari, P.S. 2001. Peranan Agen Pembaharuan/Penyuluh dalam Usaha Memberdayakan (Empowerment) Sumberdaya Manusia Pengelola Agribisnis. Orasi Ilmiah Guru Besar Tetap Ilmu Sossial Ekonomi. Bogor: Institut Pertanian Bogor.
Darmaputera, E. 2004. Pemimpin Formal, Pemimpin Informal. Harian Umum Sore Sinar Harapan, Sabtu, 03 Juli 2004. www. Sinarharapan.com. Di akses tanggal, 20 November 2007.

Departemen Kelautan dan Perikanan. 2008.

$\begin{array}{lrr}\text { Buku Panduan } & \text { Tenaga } \\ \text { Pendamping } & \text { Desa } & \text { (TPD) } \\ \text { Program } & \text { Pemberdayaan } \\ \text { Masyarakat } & \text { Pesisir } & \text { (PEMP). } \\ \text { Jakarta: } & & \text { Direktorat } \\ \text { Pemberdayaan } & & \text { Masyarakat } \\ \text { Pesisir. } & & \end{array}$

Ginting, Rata. (1999). Pemimpin Informal dalam Pembangunan Pedesaan. Ringkasan Desertasi Doktor, Sekolah Pascasarjana, Institut Pertanian Bogor.

Mardikanto, T. 1993. Penyuluhan Pembangunan Pertanian. Sebelas Maret University Press. Surakarta.

Rogers, Everett, M. 1995. Diffusion of Innovations (4-ed). New York: The Free Press.

Sarwono, S.W. 2002. Psikologi Sosial: Individu dan Teori-Teori Psikologi Sosial. Jakarta: Balai Pustaka.

Slamet, M. 2003. Membentuk Pola Perilaku Manusia Pembangunan. Diedit oleh Ida Yustina dan Ajat Sudradjat. IPB Press.

Umar, H. 2001. Metode Penelitian untuk Skripsi dan Thesis Bisnis. Jakarta: PT Raja Grafindo Persada.

Walgito. B. 2003. Psikologi Sosial Suatu Pengantar. Ed. Revisi. Andi Yogyakarta.

Rakhmat, J. 2001. Psikologi Komunikasi. Bandung. Remaja Rosdakarya. 
